\title{
Estimation of Genetic Variability Parameters for Various Quantitative Traits and Rust Resistance in Bread Wheat (Triticum aestivum L.)
}

\author{
Reena Rani*, M.S. Punia and Vikram Singh \\ Department of Genetics and Plant Breeding, CCS HAU, Hisar, Haryana, India \\ *Corresponding author
}

\begin{abstract}
Keywords
Genetic Variability, Quantitative Traits,

Rust Resistance,

Bread Wheat

Article Info

Accepted:

16 June 2018

Available Online:

10 July 2018 segregating lines of wheat during $\mathrm{F}_{4}$ and $\mathrm{F}_{5}$ generations derived from two crosses, viz., $\mathrm{WH}$ 1105 x WH 711 and RAJ 3765 x WH 711. Moderate to high values of GCV and PCV were observed for grain weight/ear, grain yield/plant, biological yield/plant, 100-grain weight, ear weight, number of tillers/plant and number of grains/ear. The heritability estimates were high for number of tillers/plant, ear weight, number of grains/ear, 100-grain weight, biological yield/plant and grain yield/plant. The heritability estimates were high for number of tillers/plant, ear weight, number of grains/ear, 100-grain weight, biological yield/plant and grain yield/plant. Genetic advance as per cent of mean was moderate for grain weight/ear, grain yield/plant, 100-grain weight, biological yield/plant, ear weight, number of tillers/plant and number of grains/ear. High heritability with high genetic advance was observed for number of tillers/plant, grain weight/ear, 100-grain weight and grain yield/plant indicating predominance of additive gene effects and possibilities of effective selection for the improvement of these characters. The reaction to yellow rust varied from highly resistant to highly susceptible among the progenies of both the generations.
\end{abstract}

\section{A B S T R A C T}

Genetic variability is prerequisite for any crop improvement program as it helps breeders in selection process. For this purpose, present study aimed to estimate genetic parameters of eleven quantitative characters along with reaction for yellow rust resistance of 243

\section{Introduction}

Wheat (Triticum aestivum L. em. Thell) is the most important cereal crop cultivated worldwide that contributes substantially to human diet and food security. It holds a prominent position in the international food grain trade because of high productivity and the acreage it occupies. Wheat provides over $20 \%$ of calories, nearly $55 \%$ of the carbohydrate and protein in human nutrition (Gupta et al., 2009). In view of ever increasing population and demand for global food production, there is an imperative need of $40-60 \%$ increase in wheat production in coming 40 years (Goutam et al., 2015). However, both biotic and abiotic stresses are major hurdles for attaining the goal. Amongst the most important fungal diseases in wheat, yellow rust is most widely devastating disease 
especially in areas with cool and moist environments. Yellow rust infects cereal crops and grasses from early growth stages to maturity of the plant causing severe yield losses (50-100\%) (Afzal et al., 2007). In order to sustain wheat production, continuous efforts are to be made to develop high yielding and disease resistant wheat genotypes. Accomplishing this goal, the systematic attempts for wheat improvements are needed through manipulation of various yield components (Hussain et al., 2007). Grain yield being a complex trait is highly influenced by many genetic factors and environmental fluctuations. Heritability and genetic advance are other important selection parameters which help the plant breeder in determining the characters for which selection would be done. Keeping in view the above perspectives, the present investigation was taken up to find out genetic variability for quantitative traits and yellow rust resistance in wheat.

\section{Materials and Methods}

The experiment was carried out on $243 \mathrm{~F}_{4}$ and $\mathrm{F}_{5}$ generation progenies generated from two crosses namely, WH 1105 x WH 711 and RAJ 3765 x WH 711, in which WH 1105 and RAJ 3765 are two yellow rust resistant parents whereas WH 711 is a rust susceptible parent. The crop was grown in research area of Wheat and Barley Section, Department of Genetics and Plant Breeding, CCS Haryana Agricultural University, Hisar, during the Rabi season of 2015-16 and 2016-17. Infector rows were planted and also artificial inoculation (using spray method) was carried out under field conditions using Pst (Puccinia striiformis) isolate as a source of inoculum. The $F_{4}$ and $F_{5}$ progenies were sown in the field in paired rows with two replications in a randomised block design (RBD). All the recommended package of practices were followed to raise the crop. To study the variability, data were recorded on five randomly selected plants of each parent and from each progeny of $\mathrm{F}_{4}$ and $\mathrm{F}_{5}$ population for grain yield and its component traits i.e., plant height $(\mathrm{cm})$, number of tillers/plant, ear length $(\mathrm{cm})$, ear weight $(\mathrm{g})$, number of grains/ear, grain weight/ear $(\mathrm{g})$, number of spikelets/ear, 100-grain weight (g), biological yield/plant (g) and harvest index (\%). Yellow rust severity (\%) was recorded for each genotype from the time of rust first appearance and then every seven days. Estimates of severity were measured according to modified Cobb's scale (Peterson et al., 1948). The data were analyzed for variabilty parameters like genotypic coefficient of variation (GCV), phenotypic coefficient of variation (PCV), broad sense heritability $\left(\mathrm{h}_{\mathrm{bs}}^{2}\right)$ and genetic advance as per cent of mean (GAM) using OPSTAT software.

\section{Results and Discussion}

\section{Analysis of variance}

The mean sum of squares with respect to seed yield and its component traits as a measure of variability in $\mathrm{F}_{4}$ and $\mathrm{F}_{5}$ generation of the two crosses, WH 1105 x WH 711 (Table 1) and RAJ 3765 x WH 711 (Table 2) indicated significant differences among the genotypes for all the characters. These differences could be used for distinguishing different genotypes from each other. Many earlier workers including Naghavi et al., (2009); Riaz-Ud-Din et al., (2010); Kaushik et al., (2013) and Maurya et al., (2014) reported high variability for different traits in wheat.

\section{Variability and heritability parameters}

For the adoption of suitable breeding programmes, the assessment of heritable and non-heritable components in the total variability observed is indispensable. The heritable component can be assessed by studying phenotypic coefficient of variation 
(PCV), genotypic coefficient of variation (GCV), heritability and predicted genetic advance. The PCV values were higher than GCV in both the crosses for all the characters indicating that the expression of these traits were influenced by the environmental conditions which confirmed the finding of Kaushik et al., (2013) and Shankarrao et al., (2010).

\section{In WH 1105 x WH 711 cross}

\section{GCV and PCV}

In $\mathrm{F}_{4}$ generation, $\mathrm{PCV}$ ranged from 5.91 for number of spikelets/ear to 23.78 for grain weight/ear whereas GCV ranged from 4.53 for ear length to 21.83 for grain weight/ear (Table 3). High GCV was observed for grain yield/plant while traits viz., 100-grain weight, biological yield/plant, ear weight and number of tillers/ plant showed moderate GCV. Rest of the traits had low values of GCV. Similarly grain yield/plant, biological yield/plant and 100-grain weight had high PCV whereas ear weight, number of tillers/plant and number of grains/ ear had moderate PCV. Rest of the traits had low values of PCV. Similar findings were also reported by Ali et al., (2008) and Kalimullah et al., (2012) for grain yield per plant and by Kumar et al., (2012a) for number of tillers/ plant and biological yield per plant.

In $\mathrm{F}_{5}$ generation, the maximum value of $\mathrm{PCV}$ was observed for grain yield/plant (24.02) and minimum for number of spikelets/ ear (5.67) whereas GCV was maximum for grain yield/plant (20.81) and minimum for ear length (4.38). The traits namely, grain weight/ ear, ear weight, harvest index, 100-grain weight and number of tillers/ plant showed moderate GCV. Rest of the traits had low GCV. Bhushan et al., (2013) observed moderate GCV for harvest index and number of tillers/plant and Degewione et al., (2013) observed high PCV for grain yield. Harvest index had high PCV while grain weight/ ear, ear weight, 100-grain weight, number of tillers/plant, biological yield/plant and number of grains/ ear had moderate PCV. Rest of the traits had low PCV which indicated low level of variability for the characters in the population under study. Choudhary et al., (2015) observed similar results for number of effective tillers/plant. The differences between PCV and GCV were relatively very small which showed least environmental influence and supported by the findings of Shankarrao et al., (2010).

\section{Heritability and genetic advance}

In $\mathrm{F}_{4}$ generation, the heritability (broad sense) estimates were higher for all the traits, except ear length, harvest index and plant height for which these estimates were moderate. Similar results were reported by Ali et al., (2008) for number of spikelets/spike, number of grains/spike, 1000-grain weight and yield/plant and Ajmal et al., (2009) for tillers/plant.

Genetic advance as per cent of mean was high for grain weight/ ear, grain yield/ plant, 100grain weight, biological yield per plant, ear weight and number of tillers/ plant whereas moderate for number of grains/ ear. Rest of the characters showed low $(<10 \%)$ values of genetic advance as per cent of mean. Johnson et al., (1955) reported that heritability value along with genetic advance was a better approach for selecting the desirable individuals rather than heritability value alone. Number of tillers/plant, ear weight, grain weight/ear, 100-grain weight, grain yield/plant and biological yield/plant had high heritability with high genetic advance. It indicates the presence of additive gene action. These results are in agreement with the earlier findings of Eid (2009) for 1000 grain-weight and Shankarrao et al., (2010) for grain weight/spike. 
In $\mathrm{F}_{5}$ generation, highest heritability (broad sense) was recorded for grain weight/ear $(87.02 \%)$ and lowest for ear length (41.19).

Heritability estimates were high for ear weight, 100-grain weight, grain yield/plant, number of spikelets/ear and number of grains/ear while moderate values of heritability were observed for the traits, namely, number of tillers/plant, harvest index, plant height, biological yield/plant and ear length. These results were supported by Khan and Naqvi (2011) for spike length and Kumar et al., (2012a) for grain yield/plant and number of grains/ear. Genetic advance as per cent of mean was high for grain yield/plant, grain weight/ear, ear weight, 100-grain weight and harvest index whereas moderate for number of tillers/ plant, number of grains/ ear and biological yield/plant.

Rest of the characters showed low $(<10 \%)$ values of genetic advance as per cent of mean. Ear weight, grain weight/ear, 100-grain weight and grain yield/plant had high heritability with high genetic advance. Genetic advance as per cent of mean ranged from 5.80 to $37.15 \%$. Similar findings were also reported by Bhushan et al., (2013) for number of tiller/plant and number of grain/spike and Degewione et al., (2013) for grain yield.

\section{In RAJ 3765 x WH 711 cross}

\section{GCV and PCV}

In $\mathrm{F}_{4}$ generation, high values of $\mathrm{GCV}$ were observed for number of tillers/plant and grain yield/plant while the traits viz., grain weight/ear, harvest index, 100-grain weight, ear weight, number of grains/ear and biological yield/plant showed moderate GCV. Rest of the traits had low ( $<10 \%)$ GCV (Table 4). Jan and Kashyap (2013) also found high GCV for number of tillers and grain yield/ plant. Grain yield/plant, number of tillers/plant, harvest index and grain weight/ear had high PCV. Ear weight, 100grain weight, biological yield/plant and number of grains/ear had moderate PCV. Rest of the traits had low $(<10 \%)$ PCV. These observations are in agreement with the earlier reports of Dutamo et al., (2015) for yield/plant and Fikre et al., (2015) for 1000 kernel weight.

In $\mathrm{F}_{5}$ generation, moderate $\mathrm{GCV}$ was observed for the traits, viz., number of tillers/ plant, grain yield/ plant, grain weight/ ear, harvest index, 100-grain weight and ear weight. Rest of the traits had low $(<10 \%)$ GCV. The traits namely, number of tillers/ plant, harvest index, grain yield/plant and grain weight/ear had high PCV whereas ear weight, 100-grain weight, number of grains/ear and biological yield/plant had moderate PCV. Rest of the traits had low $(<10 \%)$ PCV. Similar findings were also reported by Yadawad et al., (2015) and Arya et al., (2017) for grain yield/plant and Rathwa et al., (2018) for number of

productive tillers/plant followed by grain yield/plant and harvest index. Low values of GCV and PCV indicated low level of variability for the characters in the population under study.

\section{Heritability and genetic advance}

In $\mathrm{F}_{4}$ generation, heritability (broad sense) estimates were high for number of tillers/plant followed by grain weight/ear, 100-grain weight, number of grains/ear and grain yield/plant. Rest of the traits had moderate values values of heritability. Similar findings were also reported by Choudhary et al., (2015) for number of effective tillers/plant; Arya et al., (2017) for grain yield/plant and Rathwa et al., (2018) for number of productive tillers/plant followed by grain yield/plant, harvest index and grain weight/main spike. Genetic advance as per cent of mean ranged 
from 6.59 for number of spikelets/ear to 42.84 for number of tillers/plant. GAM was high for number of tillers/plant, grain weight/ear, grain yield/plant, 100-grain weight, harvest index, ear weight and number of grains/ear whereas biological yield/plant showed moderate genetic advance.

Rest of the characters showed low $(<10 \%)$ values of genetic advance as per cent of mean. High heritability coupled with high genetic advance was exhibited by number of tillers/plant, number of grains/ear, grain weight/ear, 100-grain weight, and grain yield/plant. Ear weight and harvest index had moderate heritability with high genetic advance. Similar findings were also reported by Maurya et al., (2014) for yield/plant, grains/spike and 1000-grain weight; Dutamo et al., (2015) for kernels/spike, 1000-grain weight, harvest index and grain yield.

In $\mathrm{F}_{5}$ generation, high heritability (broad sense) was recorded for grain weight/ear followed by number of tillers/plant, grain yield/plant, 100-grain weight and number of grains/ear. Moderate values of heritability were observed for rest of the traits. Genetic advance as per cent of mean was high for number of tillers/plant, grain yield/plant, grain weight/ear and harvest index whereas moderate for 100-grain weight, number of grains/ear, ear weight and biological yield/plant. Rest of the characters showed low $(<10 \%)$ values of genetic advance as per cent of mean.

Number of tillers/plant, grain weight/ear and grain yield/plant had high heritability with high genetic advance. High heritability coupled with high genetic advance was reported by Rajshree and Singh (2018) for number of tillers/plant and grain yield and Singh et al., (2018) for grain yield. Harvest index had moderate heritability with high genetic advance. Genetic advance as per cent of mean ranged from 6.86 to $36.84 \%$.

\section{Response to yellow rust}

Yellow rust infects green tissues of cereal crops within a temperature range of $11^{\circ} \mathrm{C}$ to $23^{\circ} \mathrm{C}$ and the affected plants show the symptoms of yellow-colored parallel stripes along the venations of leaf blade which are actually the characteristic of uredia that produce yellow colored uredospores. The data on disease reaction of parents, $F_{4}$ and $F_{5}$ generations revealed that all the plants of both the resistant parents (WH 1105 and RAJ 3765) were free from the symptoms of yellow rust disease, whereas, the susceptible parent (WH 711) showed the symptoms of yellow rust. The reaction to yellow rust has been described crosswise separately.

\section{Cross I: WH 1105 x WH 711}

In this cross, a total 114 plants in $\mathrm{F}_{4}$ and $\mathrm{F}_{5}$ generations were screened by spraying the urediospores of prevalent races under natural field conditions. In $\mathrm{F}_{4}$ generation, 84 plants showed no infection, 7 showed traces of infection, 8 plants showed $5-10$ on the scale, 20 was shown by 3 plants, 40 by 2 plants, 60 by 7 plants and 100 by 3 plants (Table 5). Similarly, in $\mathrm{F}_{5}$ generation, 55 plants showed no infection, 39 plants were on 5-10 scale, 13 showed 20 percent infection, 6 plants showed 40 percent infection and 1 showed 60 percent severity (Table 6).

Most of the plants which were highly resistant in $\mathrm{F}_{4}$ generation were also identified as highly resistant in $\mathrm{F}_{5}$ generation. Plant No. 6, 7, 8, 27 , 37, 42, 96, 97, 106, 107, 109, 113 and 114 were moderately to highly susceptible in $\mathrm{F}_{4}$ but they appeared as resistant to highly resistant in $\mathrm{F}_{5}$ progenies whereas plant No. 10, $11,14,15,16,20,32,36,38,44,71,103$ and 111 were moderately to highly resistant in $\mathrm{F}_{4}$ but they appeared as to be susceptible to highly susceptible in $\mathrm{F}_{5}$ progenies. 
Table.1 Mean sum of squares for 11 morphological characters in $\mathrm{F}_{4}$ and $\mathrm{F}_{5}$ generations of the cross WH 1105 x WH 711 in wheat

\begin{tabular}{|c|c|c|c|c|c|c|c|c|c|c|c|c|c|}
\hline S.V. & & d.f. & $\begin{array}{c}\text { Plant } \\
\text { height } \\
(\mathrm{cm})\end{array}$ & $\begin{array}{l}\text { No. of } \\
\text { Tillers } \\
\text { / nlant }\end{array}$ & $\begin{array}{c}\text { Ear } \\
\text { lengt } \\
\text { h }\end{array}$ & $\begin{array}{c}\text { Ear } \\
\text { weigh } \\
\text { t (g) }\end{array}$ & $\begin{array}{c}\text { No. of } \\
\text { Grains/ea } \\
\mathbf{r}\end{array}$ & $\begin{array}{c}\text { Grain } \\
\text { weight } \\
\text { / ear }\end{array}$ & $\begin{array}{c}\text { No. of } \\
\text { spikelets } \\
\text { / ear }\end{array}$ & $\begin{array}{c}100 \\
\text { grain } \\
\text { wt. }\end{array}$ & $\begin{array}{l}\text { Grain } \\
\text { yield/ } \\
\text { nlant }\end{array}$ & $\begin{array}{c}\text { Biologica } \\
\text { I yield/ } \\
\text { nlant (g) }\end{array}$ & $\begin{array}{c}\text { Harvest } \\
\text { index } \\
(\%)\end{array}$ \\
\hline \multirow[t]{2}{*}{ Replicatio } & $\mathrm{F}$ & 1 & 42.67 & 0.54 & 0.98 & 0.05 & 1.68 & 0.15 & 0.65 & 0.19 & 3.29 & 18.66 & $34.35^{*}$ \\
\hline & $\mathrm{F}$ & 1 & 0.67 & 0.14 & 1.27 & 0.16 & 12.79 & 0.09 & 1.15 & 0.003 & 1.92 & 6.79 & 6.08 \\
\hline \multirow[t]{2}{*}{ Treatment } & $\mathrm{F}$ & 11 & $91.33^{*}$ & $1.99 * *$ & $0.85^{*}$ & $0.69 *$ & $78.60 * *$ & $0.56 * *$ & $2.73 * *$ & $1.20 *$ & $16.21 *$ & $61.15 * *$ & $26.93 * *$ \\
\hline & $\mathrm{F}$ & 11 & $72.60 *$ & $1.33 * *$ & $0.94 *$ & $0.51 *$ & $77.09 * *$ & $0.42 * *$ & $2.53 * *$ & $0.67 *$ & $13.19 *$ & $19.03 * *$ & $112.59 *$ \\
\hline \multirow[t]{2}{*}{ Error } & $\mathrm{F}$ & 11 & 32.89 & 0.19 & 0.27 & 0.05 & 10.34 & 0.05 & 0.54 & 0.11 & 1.45 & 7.52 & 8.25 \\
\hline & $\mathrm{F}$ & 11 & 27.30 & 0.34 & 0.39 & 0.07 & 16.94 & 0.03 & 0.42 & 0.09 & 1.88 & 7.32 & 31.72 \\
\hline \multirow[t]{2}{*}{ C.V. (\%) } & $\mathrm{F}$ & & 6.65 & 7.43 & 4.32 & 7.64 & 5.23 & 9.44 & 3.39 & 8.82 & 9.48 & 10.32 & 5.94 \\
\hline & $\mathrm{F}$ & & 6.11 & 10.28 & 5.24 & 8.79 & 6.54 & 7.16 & 3.03 & 8.02 & 11.99 & 9.71 & 13.70 \\
\hline \multirow[t]{2}{*}{ CD } & $\mathrm{F}$ & & 11.37 & 0.86 & 1.02 & 0.47 & 6.38 & 0.43 & 1.45 & 0.65 & 2.39 & 5.44 & 5.70 \\
\hline & $\mathrm{F}$ & & 10.36 & 1.16 & 1.24 & 0.53 & 8.16 & 0.34 & 1.29 & 0.61 & 2.72 & 5.37 & 11.17 \\
\hline
\end{tabular}

Table.2 Mean sum of squares for 11 morphological characters in $F_{4}$ and $F_{5}$ generations of the cross RAJ 3765 x WH 711 in wheat

\begin{tabular}{|c|c|c|c|c|c|c|c|c|c|c|c|c|c|}
\hline S.V. & & d.f. & $\begin{array}{c}\text { Plant } \\
\text { height } \\
(\mathrm{cm})\end{array}$ & $\begin{array}{l}\text { No. of } \\
\text { Tillers } \\
\text { / nlant }\end{array}$ & $\begin{array}{c}\text { Ear } \\
\text { lengt } \\
\text { h }\end{array}$ & $\begin{array}{c}\text { Ear } \\
\text { weigh } \\
t(g)\end{array}$ & $\begin{array}{c}\text { No. of } \\
\text { Grains/ea } \\
\mathbf{r}\end{array}$ & $\begin{array}{c}\text { Grain } \\
\text { weight } \\
\text { / ear }\end{array}$ & $\begin{array}{c}\text { No. of } \\
\text { spikelets } \\
\text { / ear }\end{array}$ & $\begin{array}{c}100 \\
\text { grain } \\
\text { wt. }\end{array}$ & $\begin{array}{l}\text { Grain } \\
\text { yield/ } \\
\text { nlant }\end{array}$ & $\begin{array}{c}\text { Biologica } \\
\text { l yield/ } \\
\text { nlant (g) }\end{array}$ & $\begin{array}{c}\text { Harvest } \\
\text { index } \\
(\%)\end{array}$ \\
\hline \multirow{2}{*}{ Replicatio } & $\mathrm{F}$ & 1 & 44.91 & 0.41 & 0.47 & 0.04 & 1.48 & 0.05 & 0.16 & 0.24 & 1.42 & 7.97 & 61.75 \\
\hline & $\mathrm{F}$ & 1 & 25.52 & 0.12 & 0.67 & 0.20 & 1.35 & 0.004 & 0.63 & 0.07 & 0.99 & 1.80 & 0.42 \\
\hline \multirow[t]{2}{*}{ Treatment } & $\mathrm{F}$ & 13 & $59.35^{*}$ & $5.17 * *$ & $1.03^{*}$ & $0.46^{*}$ & $107.22 * *$ & $0.52 * *$ & $3.10 * *$ & $0.73^{*}$ & $18.56^{*}$ & $29.08 * *$ & $140.59 *$ \\
\hline & $\mathrm{F}$ & 13 & $67.45^{*}$ & $4.49 * *$ & $1.02 *$ & $0.42 *$ & $98.07 * *$ & $0.52 * *$ & $3.12 * *$ & $0.56^{*}$ & $14.84 *$ & $19.71 * *$ & $143.33^{*}$ \\
\hline \multirow[t]{2}{*}{ Error } & $\mathrm{F}$ & 13 & 22.49 & 0.26 & 0.28 & 0.12 & 15.48 & 0.04 & 1.15 & 0.10 & 2.97 & 7.86 & 45.36 \\
\hline & $\mathrm{F}$ & 13 & 20.60 & 0.44 & 0.32 & 0.18 & 22.90 & 0.05 & 1.06 & 0.12 & 1.73 & 8.32 & 36.90 \\
\hline \multirow[t]{2}{*}{ C.V. (\%) } & $\mathrm{F}$ & & 5.52 & 7.12 & 4.44 & 10.97 & 6.53 & 7.98 & 5.15 & 7.91 & 13.26 & 9.50 & 15.26 \\
\hline & $\mathrm{F}$ & & 5.38 & 9.19 & 4.69 & 12.72 & 7.77 & 8.11 & 4.83 & 8.31 & 9.67 & 9.33 & 13.70 \\
\hline \multirow[t]{2}{*}{ CD } & $\mathrm{F}$ & & 9.39 & 1.01 & 1.04 & 0.70 & 7.79 & 0.39 & 2.13 & 0.64 & 3.41 & 5.55 & 13.34 \\
\hline & $\mathrm{F}$ & & 8.99 & 1.31 & 1.12 & 0.83 & 9.48 & 0.43 & 2.04 & 0.69 & 2.60 & 5.71 & 12.03 \\
\hline
\end{tabular}


Table.3 Genetic variability parameters for 11 quantitative traits in $\mathrm{F}_{4}$ and $\mathrm{F}_{5}$ generations of the cross WH $1105 \mathrm{x}$ WH 711 in wheat

\begin{tabular}{|c|c|c|c|c|c|c|c|c|}
\hline \multirow[t]{2}{*}{ Characters } & & \multirow{2}{*}{$\underset{\text { SE }}{\operatorname{Mean} \pm}$} & \multirow[t]{2}{*}{ Range } & \multicolumn{2}{|c|}{ Coefficient of variation } & \multirow{2}{*}{$\begin{array}{l}\text { Heritability } \\
\text { (bs) }(\%)\end{array}$} & \multirow[t]{2}{*}{$\begin{array}{l}\text { Genetic } \\
\text { advance }\end{array}$} & \multirow{2}{*}{$\begin{array}{l}\text { Genetic } \\
\text { advance as } \\
\mathbf{5 \%} \text { of mean }\end{array}$} \\
\hline & & & & $\begin{array}{c}\text { Genotypic } \\
(\%)\end{array}$ & $\begin{array}{c}\text { Phenotypic } \\
(\%)\end{array}$ & & & \\
\hline \multirow[t]{2}{*}{ Plant height (cm) } & $\mathrm{F}_{4}$ & $86.27 \pm 5.73$ & $66.27-104.85$ & 6.27 & 9.13 & 47.06 & 7.64 & 8.86 \\
\hline & $\mathrm{F}_{5}$ & $85.58+5.22$ & $68.3-99.75$ & 5.56 & 8.26 & 45.36 & 6.60 & 7.72 \\
\hline \multirow{2}{*}{$\begin{array}{l}\text { Number of tillers/ } \\
\text { plant }\end{array}$} & $\mathrm{F}_{4}$ & $5.85 \pm 0.43$ & $3.5-9.1$ & 16.19 & 17.81 & 82.61 & 1.77 & 30.31 \\
\hline & $\mathrm{F}_{5}$ & $5.68 \pm 0.59$ & $4-9.5$ & 12.34 & 16.06 & 59.04 & 1.11 & 19.53 \\
\hline \multirow[t]{2}{*}{ Ear length (cm) } & $\mathrm{F}_{4}$ & $11.92 \pm 0.51$ & $9.94-13.86$ & 4.53 & 6.26 & 52.30 & 0.80 & 6.74 \\
\hline & $\mathrm{F}_{5}$ & $11.94+0.63$ & $10.2-14$ & 4.38 & 6.83 & 41.19 & 0.69 & 5.80 \\
\hline \multirow[t]{2}{*}{ Ear weight (g) } & $\mathrm{F}_{4}$ & $3.07 \pm 0.23$ & $1.85-4.395$ & 18.30 & 19.84 & 85.15 & 1.07 & 34.80 \\
\hline & $\mathrm{F}_{5}$ & $3.03 \pm 0.27$ & $1.87-4.22$ & 15.53 & 17.85 & 75.74 & 0.84 & 27.85 \\
\hline \multirow{2}{*}{$\begin{array}{l}\text { Number of grains/ } \\
\text { ear }\end{array}$} & $\mathrm{F}_{4}$ & $61.50 \pm 3.22$ & $48.25-78.6$ & 9.50 & 10.84 & 76.75 & 10.54 & 17.14 \\
\hline & $\mathrm{F}_{5}$ & $62.95 \pm 4.12$ & $48.65-80.4$ & 8.71 & 10.89 & 63.96 & 9.03 & 14.35 \\
\hline \multirow{2}{*}{$\begin{array}{l}\text { Grain weight/ ear } \\
\text { (g) }\end{array}$} & $\mathrm{F}_{4}$ & $2.32 \pm 0.22$ & $1.295-3.725$ & 21.83 & 23.78 & 84.26 & 0.96 & 41.28 \\
\hline & $\mathrm{F}_{5}$ & $2.39 \pm 0.17$ & $1.34-3.69$ & 18.53 & 19.87 & 87.02 & 0.85 & 35.61 \\
\hline \multirow{2}{*}{$\begin{array}{l}\text { Number of spikelets/ } \\
\text { ear }\end{array}$} & $\mathrm{F}_{4}$ & $21.62 \pm 0.73$ & $17.55-24.55$ & 4.84 & 5.91 & 67.08 & 1.77 & 8.17 \\
\hline & $\mathrm{F}_{5}$ & $21.42 \pm 0.65$ & $18.25-24.03$ & 4.82 & 5.67 & 71.52 & 1.79 & 8.36 \\
\hline \multirow[t]{2}{*}{100 grain wt (g) } & $\mathrm{F}_{4}$ & $3.75 \pm 0.33$ & $1.96-6.01$ & 19.68 & 21.56 & 83.29 & 1.39 & 37.00 \\
\hline & $\mathrm{F}_{5}$ & $3.82 \pm 0.31$ & $2.2-5.73$ & 14.01 & 16.14 & 75.33 & 0.96 & 25.05 \\
\hline \multirow{2}{*}{$\begin{array}{l}\text { Grain yield/ plant } \\
\text { (g) }\end{array}$} & $\mathrm{F}_{4}$ & $12.71 \pm 1.20$ & $6.92-20.96$ & 21.37 & 23.37 & 83.56 & 5.12 & 40.24 \\
\hline & $\mathrm{F}_{5}$ & $11.43 \pm 1.37$ & $7.68-18.81$ & 20.81 & 24.02 & 75.09 & 4.24 & 37.15 \\
\hline \multirow{2}{*}{$\begin{array}{l}\text { Biological yield/ } \\
\text { plant }(\mathrm{g})\end{array}$} & $\mathrm{F}_{4}$ & $26.56+2.74$ & $15.08-38.9$ & 19.49 & 22.05 & 78.09 & 9.43 & 35.48 \\
\hline & $\mathrm{F}_{5}$ & $27.85 \pm 2.70$ & $22.05-36.10$ & 8.69 & 13.03 & 44.45 & 3.32 & 11.93 \\
\hline \multirow{2}{*}{ Harvest index (\%) } & $\mathrm{F}_{4}$ & $48.36+2.87$ & $36.79-53.88$ & 6.32 & 8.67 & 53.10 & 4.59 & 9.48 \\
\hline & $\mathrm{F}_{5}$ & $41.11 \pm 5.63$ & $31.77-52.50$ & 15.47 & 20.66 & 56.04 & 9.81 & 23.85 \\
\hline
\end{tabular}


Table.4 Genetic variability parameters for 11 quantitative traits in $\mathrm{F}_{4}$ and $\mathrm{F}_{5}$ generations of the cross RAJ $3765 \mathrm{x}$ WH 711 in wheat

\begin{tabular}{|c|c|c|c|c|c|c|c|c|}
\hline \multirow[t]{2}{*}{ Characters } & & \multirow[t]{2}{*}{ Mean $\pm \mathrm{SE}$} & \multirow[t]{2}{*}{ Range } & \multicolumn{2}{|c|}{ Coefficient of variation } & \multirow{2}{*}{$\begin{array}{l}\text { Heritability } \\
\text { (bs) }(\%)\end{array}$} & \multirow[t]{2}{*}{$\begin{array}{l}\text { Genetic } \\
\text { advance }\end{array}$} & \multirow{2}{*}{$\begin{array}{l}\text { Genetic } \\
\text { advance as } \\
5 \% \text { of mean }\end{array}$} \\
\hline & & & & $\begin{array}{c}\text { Genotypic } \\
(\%)\end{array}$ & $\begin{array}{c}\text { Phenotypic } \\
(\%)\end{array}$ & & & \\
\hline \multirow[t]{2}{*}{ Plant height (cm) } & $\mathrm{F}_{4}$ & $85.88+4.74$ & $74.70-98.08$ & 5.00 & 7.45 & 45.07 & 5.94 & 6.92 \\
\hline & $\mathrm{F}_{5}$ & $84.43 \pm 4.54$ & $73.32-98.42$ & 5.73 & 7.86 & 53.24 & 7.28 & 8.62 \\
\hline \multirow{2}{*}{$\begin{array}{l}\text { Number of tillers/ } \\
\text { plant }\end{array}$} & $\mathrm{F}_{4}$ & $7.16 \pm 0.51$ & $3.45-10.10$ & 21.87 & 23.00 & 90.41 & 3.07 & 42.84 \\
\hline & $\mathrm{F}_{5}$ & $7.21 \pm 0.66$ & $3.89-9.8$ & 19.73 & 21.76 & 82.18 & 2.66 & 36.84 \\
\hline \multirow[t]{2}{*}{ Ear length (cm) } & $\mathrm{F}_{4}$ & $11.83 \pm 0.52$ & $10.00-13.89$ & 5.22 & 6.81 & 58.82 & 0.98 & 8.25 \\
\hline & $\mathrm{F}_{5}$ & $12.1 \pm 0.57$ & $10.83-14.3$ & 4.89 & 6.77 & 52.09 & 0.88 & 7.27 \\
\hline \multirow[t]{2}{*}{ Ear weight (g) } & $\mathrm{F}_{4}$ & $3.20 \pm 0.35$ & $2.12-4.62$ & 12.80 & 16.86 & 57.64 & 0.64 & 20.02 \\
\hline & $\mathrm{F}_{5}$ & $3.31 \pm 0.42$ & $2.36-4.81$ & 10.44 & 16.46 & 40.25 & 0.45 & 13.65 \\
\hline \multirow{2}{*}{$\begin{array}{l}\text { Number of grains / } \\
\text { ear }\end{array}$} & $\mathrm{F}_{4}$ & $60.25 \pm 3.93$ & $42.45-79.90$ & 11.24 & 13.00 & 74.76 & 12.06 & 20.02 \\
\hline & $\mathrm{F}_{5}$ & $61.61 \pm 4.78$ & $44.2-80.79$ & 9.95 & 12.62 & 62.14 & 9.95 & 16.16 \\
\hline \multirow{2}{*}{$\begin{array}{l}\text { Grain weight/ ear } \\
\text { (g) }\end{array}$} & $\mathrm{F}_{4}$ & $2.48 \pm 0.20$ & $1.21-3.81$ & 19.75 & 21.30 & 85.96 & 0.94 & 37.71 \\
\hline & $\mathrm{F}_{5}$ & $2.66 \pm 0.22$ & $1.42-3.78$ & 18.30 & 20.02 & 83.57 & 0.92 & 34.46 \\
\hline \multirow{2}{*}{$\begin{array}{l}\text { Number of } \\
\text { spikelets/ ear }\end{array}$} & $\mathrm{F}_{4}$ & $20.86 \pm 1.07$ & $16.50-24.20$ & 4.73 & 6.99 & 45.79 & 1.37 & 6.59 \\
\hline & $\mathrm{F}_{5}$ & $21.35 \pm 1.03$ & $17.05-25.05$ & 4.75 & 6.78 & 49.17 & 1.46 & 6.86 \\
\hline \multirow[t]{2}{*}{100 grain wt (g) } & $\mathrm{F}_{4}$ & $4.10 \pm 0.32$ & $2.20-5.79$ & 13.65 & 15.78 & 74.85 & 0.99 & 24.34 \\
\hline & $\mathrm{F}_{5}$ & $4.21 \pm 0.35$ & $2.62-5.70$ & 11.08 & 13.85 & 64.02 & 0.77 & 18.26 \\
\hline \multirow{2}{*}{$\begin{array}{l}\text { Grain yield/ plant } \\
\text { (g) }\end{array}$} & $\mathrm{F}_{4}$ & $13.00 \pm 1.72$ & $6.14-19.25$ & 21.47 & 25.23 & 72.39 & 4.89 & 37.63 \\
\hline & $\mathrm{F}_{5}$ & $13.59 \pm 1.31$ & $7.13-17.78$ & 18.84 & 21.17 & 79.14 & 4.69 & 34.52 \\
\hline \multirow{2}{*}{$\begin{array}{l}\text { Biological yield/ } \\
\text { plant (g) }\end{array}$} & $\mathrm{F}_{4}$ & $29.54 \pm 2.80$ & 18.73-38.39 & 11.04 & 14.56 & 57.45 & 5.09 & 17.24 \\
\hline & $\mathrm{F}_{5}$ & $30.92 \pm 2.88$ & $22.25-38$ & 7.72 & 12.11 & 40.65 & 3.13 & 10.14 \\
\hline \multirow[t]{2}{*}{ Harvest index (\%) } & $\mathrm{F}_{4}$ & $44.13 \pm 6.73$ & $29.61-52.49$ & 15.64 & 21.85 & 51.22 & 10.17 & 23.05 \\
\hline & $\mathrm{F}_{5}$ & $44.33 \pm 6.07$ & $30.62-51.93$ & 16.45 & 21.43 & 59.05 & 11.55 & 26.05 \\
\hline
\end{tabular}


Table.5 Reaction to yellow rust in $\mathrm{F}_{4}$ generation of WH $1105 \times \mathrm{x}$ WH 711

\begin{tabular}{|c|c|l|c|}
\hline $\begin{array}{c}\text { Per cent leaf } \\
\text { area infected }\end{array}$ & Reaction & Plant number & $\begin{array}{c}\text { Number of } \\
\text { plants }\end{array}$ \\
\hline T (Traces) & HR & $15,28,55,87,98,111$ and 112 & 7 \\
\hline $5-10$ & R & $9,23,39,44,66,73,108$ and 110 & 8 \\
\hline 20 & MR & 40,95 and 97 & 3 \\
\hline 40 & MS & 8 and 114 \\
\hline 60 & S & $7,27,37,42,107,109$ and 113 & 2 \\
\hline 100 & HS & 6,96 and 106 & 3 \\
\hline
\end{tabular}

Table.6 Reaction to yellow rust in $\mathrm{F}_{5}$ generation of WH 1105 x WH 711

\begin{tabular}{|c|c|c|c|}
\hline $\begin{array}{l}\text { Per cent leaf } \\
\text { area infected }\end{array}$ & Reaction & Plant number & $\begin{array}{l}\text { Number of } \\
\text { plants }\end{array}$ \\
\hline $\mathrm{T}$ (Traces) & HR & -- & 0 \\
\hline $5-10$ & $\mathrm{R}$ & $\begin{array}{l}1,2,3,4,6,8,9,12,13,18,19,24,28,35,39,41 \\
48,53,54,62,63,64,66,67,74,75,81,84,86, \\
91,92,94,95,99,104,106,110,113 \text { and } 114\end{array}$ & 39 \\
\hline 20 & MR & $\begin{array}{l}10,11,14,15,16,20,32,36,38,44,71,103 \text { and } \\
111\end{array}$ & 13 \\
\hline 40 & MS & $17,29,37,73,93$ and 112 & 6 \\
\hline 60 & S & 42 & 1 \\
\hline 100 & HS & -- & 0 \\
\hline
\end{tabular}

Table.7 Reaction to yellow rust in $\mathrm{F}_{4}$ generation of RAJ 3765 x WH 711

\begin{tabular}{|c|c|l|c|}
\hline $\begin{array}{c}\text { Per cent leaf } \\
\text { area infected }\end{array}$ & Reaction & Plant number & $\begin{array}{c}\text { Number of } \\
\text { plants }\end{array}$ \\
\hline T (Traces) & HR & $\begin{array}{l}7,24,32,33,66,67,79,81,88,116,118,120,126 \\
\text { and } 128\end{array}$ & 14 \\
\hline $5-10$ & R & $1,8,37,50,52,54,70,77,78,89,119,124$ and 129 & 13 \\
\hline 20 & MR & $19,34,45,49,72,82,95,115,121$ and 123 & 10 \\
\hline 40 & MS & 46,83 and 122 & 3 \\
\hline 60 & S & $47,73,117,125$ and 127 & 5 \\
\hline 100 & HS & 23 and 90 \\
\hline
\end{tabular}


Table.8 Reaction to yellow rust in $\mathrm{F}_{5}$ generation of RAJ 3765 x WH 711

\begin{tabular}{|c|c|c|c|}
\hline $\begin{array}{l}\text { Per cent leaf } \\
\text { area infected }\end{array}$ & Reaction & Plant number & $\begin{array}{c}\text { Number of } \\
\text { plants }\end{array}$ \\
\hline $\mathrm{T}$ (Traces) & HR & -- & 0 \\
\hline $5-10$ & $\mathrm{R}$ & $12,28,31,38,40,108,120,122$ and 128 & 9 \\
\hline 20 & MR & $\begin{array}{l}7,10,26,27,32,35,36,37,43,50,53,56,61,62 \text {, } \\
73,75,76,77,78,82,83,88,89,91,102,106 \text { and } \\
127\end{array}$ & 27 \\
\hline 40 & MS & $34,39,46,47,48,49,51,52,57,64$ and 90 & 11 \\
\hline 60 & $\mathrm{~S}$ & 21,23 and 33 & 3 \\
\hline 100 & HS & -- & 0 \\
\hline
\end{tabular}

\section{Cross II: Raj 3765 x WH 711}

In this cross, a total of 129 plants in $\mathrm{F}_{4}$ and $\mathrm{F}_{5}$ generations were screened for reaction to yellow rust under natural field conditions. In $\mathrm{F}_{4}$ generation, 82 plants showed no infection, 14 showed traces of infection, 13 showed 510 on the scale, 20 was shown by 10 plants, 40 by 3 plants, 60 by 5 plants and 100 by 2 plants (Table 7). Similarly, in $\mathrm{F}_{5}$ generation, 79 plants showed no infection, 9 plants were on 5-10 scale, 27 showed 20 percent infection, 11 plants showed 40 percent infection and 3 showed 60 percent severity (Table 8). Most of the plants which were highly resistant in $\mathrm{F}_{4}$ generation were also identified as highly resistant in $\mathrm{F}_{5}$ generation. Plant No. 73, 83, 117, 122, 125 and 127 were moderately to highly susceptible in $\mathrm{F}_{4}$ but they appeared as resistant to highly resistant in $\mathrm{F}_{5}$ progenies whereas plant No. $21,33,34$, 39, 48, 49, 51, 52, 57 and 64 and were moderately to highly resistant in $\mathrm{F}_{4}$ but they appeared as to be susceptible to highly susceptible in $\mathrm{F}_{5}$ progenies.

In conclusion, the present study was conducted with $\mathrm{F}_{4}$ and $\mathrm{F}_{5}$ generations of two crosses, viz., WH $1105 \times$ WH 711 and RAJ $3765 \times$ WH 711 of wheat to assess the genetic variability for yield and its component traits and disease reaction for yellow rust. Analysis of variance revealed that highly significant differences among the treatments for all the characters, indicating significant differences among the genotypes for all the characters. The minimum differences between GCV and PCV values showed least influence of environment. The reaction to yellow rust varied from highly resistant to highly susceptible among the plants of both the generations.

Most of the plants which were highly resistant in $\mathrm{F}_{4}$ generation were also identified as highly resistant in $\mathrm{F}_{5}$ generation. High to medium values of PCV and GCV were recorded for grain weight/ear, grain yield/plant, 100-grain weight, biological yield/plant, ear weight and number of tillers/plant which suggested the possibility of improving these traits through selection.

The characters having high heritability estimates are of immense importance as it permits selection at phenotypic level and there would be greater correspondence between phenotypic worth and breeding values. High heritability along with high genetic advance were recorded for number of tillers/plant, ear weight, grain weight/ear, 100-grain weight and grain yield/plant which shows a strong contribution of additive genetic variance in expression of the traits 
indicating that simple selection scheme would be sufficient for these traits can help in the improvement of grain yield.

\section{Acknowledgement}

I would like to thank Department of science and technology (DST-INSPIRE) for providing fellowship and other grants.

\section{References}

Afzal, S.N., Haque, M., Ahmedani, M., Bashir, S., Rattu, A. 2007. Assessment of yield losses caused by Puccinia striiformis triggering stripe rust in the most common wheat varieties. Pak. J. Bot., 39: 2127- 2134.

Ajmal, S., Zakir, N. and Mujahid, M.Y. 2009. Estimation of genetic parameters and character association in wheat. J. Agric. Biol. Sci., 1(1): 15-18.

Ali, Y., Atta, B.M., Akhter, J., Monmevux, P. and Lateef, Z. 2008. Genetic variability, association and diversity studies in wheat (Triticum aestivum L.). Pak. J. Bot., 40(5): 2087-2097.

Arya, V.K., Singh, V., Kumar, L., Kumar, R., Kumar, P. and Chand, P. 2017. Genetic variability and diversity analysis for yield and its components in wheat (Triticum aestivum L.) Indian J. Agric. Res., 51(2): 128-134.

Bhushan, B., Gaurav, S.S., Kumar, R., Rishi Pal, Panday, M., Kumar, A., Bharti, S., Nagar, S.S., Rahul, V.P. 2013. Genetic variability, heritability and genetic advance in bread wheat (Triticum aestivum L.). Environment \& Ecology, 31(2): 405-407.

Choudhary, R.C., Sharma, N.K., Kumar, R. and Kumar, M. 2015. Genetic variability, heritability and genetic advance in wheat under different normal and heat stressed environments. Elect. J. of Pl. Breed., 6(4): 1082-1087.
Degewione, A., Dejene, T. and Sharif, M 2013. Genetic variability and traits association in bread wheat (Triticum aestivum L.) genotypes. Int. Res. J. Agri. Sci., 1(2): 19-29.

Dutamo, D., Alamerew, S., Dr. Firdisa, Fikre, E.G. 2015. Genetic variability in bread wheat (Triticum aestivum L.) germplasm for yield and yield component traits. Journal of Biology, Agriculture and Healthcare, 5(13): 140-147.

Eid, M.H. 2009. Estimation of heritability and genetic advance of yield traits in wheat (Triticum aestivum L.) under drought condition. Int. J. Genet. Mol. Biol., 1(7): 115-120.

Fikre, G., Alamerew, S., Tadesse, Z. 2015. Genetic variability studies in bread wheat (Triticum aestivum L.) genotypes at Kulumsa Agricultural Research Center, South East Ethiopia. Journal of Biology, Agriculture and Healthcare, 5(7): 89-98.

Goutam, U., Kukreja, S., Yadav, R., Salaria, N., Thakur, K. and Goyal, A.K. 2015. Recent trends and perspectives of molecular markers against fungal diseases in wheat. Frontiers in microbiology, 6:861. doi: 10.3389/fmicb.2015.00861

Gupta, P.K., Peter, L. and Mir, R.R. 2009. Marker-assisted wheat breeding present status and future possibilities. Mol. Breed., 7: 921-935.

Hussain, S.S. and Qamar, R. 2007. Wheat genomics: challenges and alternative strategies. Proc. Pakistan Acad. Sci., 44(4): 305-327.

Jan, N. and Kashyap, S.C. 2013.Studies on genetic variability in wheat (Triticum aestivum L.) under temperate conditions of Kashmir. Inter. J. Scie. Res., 5: 1442 1445.

Johnson, H.W., Robinson, H.F. and Comstock, R.E. 1955. Estimates of genetic and environmental variability in 
soybean. Agron. J., 47: 314-318.

Kalimullah, Khan, S.J., Irfaq, V. and Rahman, H.U. 2012. Genetic variability, correlation and diversity studies in bread wheat (Triticum aestivum L.) germplasm. The Journal of Animal \& Plant Sciences, 22(2): 330-333.

Kaushik, S.K., Tomar, D.S., Dixit, A.K. and Saxena, A.K. 2013. Assessment of wheat varieties in Central India under changed climatic scenario. Wudpecker J. Agric. Res., 2(2): 64-66.

Khan, N. and Naqvi, F.N. 2011. Heritability of morphological traits in bread wheat advanced lines under irrigated and nonirrigated conditions. Asian J. Agri. Sci., 3(3): 215-222.

Kumar, A., Sirohi, A. and Kumar, S. 2012a. Studies of selection parameter in common bread wheat (Triticum aestivum L.). Int. J. Engg. Sci. Res., 2(2-5): 9094.

Maurya, M., Chaurasia, A. K., Kumar, A., Maurya, C. L., Bara, B. M., kumar, M. and Rai, P. K. 2014. Genetic variability for seed yield and its component characters in wheat (Triticum Aestivum L.) under Allahabad agro climatic conditions. Int. J. Recent Devel. Engg. Tech., 2(4): 124-126.

Naghavi, M.R., Monafared, S.R., Ahkami, A.H. and Ombidbakhsh, M.A. 2009. Genetic variation of durum wheat landraces and cultivars using morphological and protein markers. World Acad. Sci. Engg. Technol., 49: 73-75.

Peterson, R.F., Campbell, A.B. and Hannah, A.E. 1948. A diagrammatic scale for estimating rust intensity of leaves and stem of cereals. Can J. Res. Sect. C., 26: 496-500.

Rajshree and Singh, S.K. 2018. Assessment of genetic diversity in promising bread wheat (Triticum aestivum L.) genotypes. Int. J. Curr. Microbiol. App. Sci., 7(3): 676-684.

Rathwa, H.K., Pansuriya, A.G., Patel, J.B. and Jalu, R.K. 2018. genetic variability, heritability and genetic advance in durum wheat (Triticum durum Desf.). Int.J.Curr.Microbiol.App.Sci., $\quad 7(1)$ : 1208-1215.

Riaz-Ud-Din, Subhani, G.M., Ahmad, N., Hussain, M. and Rehman, A.U. 2010. Effect of temperature on development and grain formation in spring wheat. Pak. J. Bot., 42(2): 896-899.

Shankarrao, B.S., Mukherjee, S., Pal., A.K. and De, D.K. 2010. Estimation of variability for yield parameters in bread wheat (Triticum aestivum L.) grown in Gangetic West Bengal. Elect. J. Pl. Breed., 1(4): 764-768.

Singh, G., Kumar, P., Kumar, R. and Gangwar, L. K. 2018. Genetic diversity analysis for various morphological and quality traits in bread wheat (Triticum aestivum L.) Journal of Applied and Natural Science, 10(1): 24-29.

Yadawad, A., Hanchinal, R.R., Nadaf, H.L., Desai, S.A., Biradar, S. and Rudra, V. 2015. Genetic variability and heritability estimates for yield attributes and leaf rust resistance in $\mathrm{F}_{3}$ population of wheat (Triticum aestivum L.). Bioscan, 10(2): 935-938..

\section{How to cite this article:}

Reena Rani, M.S. Punia and Vikram Singh. 2018. Estimation of Genetic Variability Parameters for Various Quantitative Traits and Rust Resistance in Bread Wheat (Triticum aestivum L.). Int.J.Curr.Microbiol.App.Sci. 7(07): 1955-1966. doi: https://doi.org/10.20546/ijcmas.2018.707.230 